\title{
Assemblée des membres virtuelle 2020
}

\section{Marianne Roth}

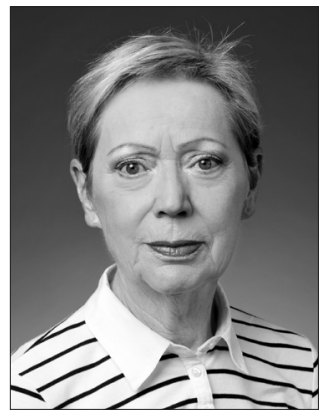

Cette année, la 43ème assemblée des membres de l'ASP était prévue initialement le 26 mars 2020. L'invitation et lordre du jour, ainsi que les documents pertinents, ont été envoyés aux membres trois semaines avant la date - avant que le comité ne prenne une décision quant à la tenue ou non de lassemblée. En fin de compte, l'assemblée des membres de cette année, comme de nombreux autres événements, a été victime du virus COVID-19. Après avoir constaté qu'une nouvelle date en présence physique des membres et des représentants de l'ASP séloignait de plus en plus, tout en sachant qu'il était primordial que le comité soit déchargé, afin de lui permettre de continuer à travailler avec un budget approuvé, et qu'il était nécessaire que les personnes soient élues aux différentes fonctions, nous avons décidé de réaliser l'assemblée des membres par écrit. Les formulaires de vote ont été transmis aux membres par courriel ou courrier le 4 juin 2020 avec la prière de nous les retourner remplis au plus tard le 26 juin 2020. Tous les points ont été approuvés à une large majorité et la décharge a été donnée au comité avec une abstention. Les membres ont également approuvé le budget et les cotisations au montant inchangé. Il convient également de mentionner la révision indispensable du code de déontologie qui a été approuvée. En ce qui concerne les élections, Veronica Defièbre a été réélue pour deux ans en tant que vice-présidente et membre du comité. Ont également été réélus Dimitra Katla à la fonction de médiatrice pour la Suisse romande et le réviseur Bruno Forster de Fiscale Treuhand. Marie Anne Nauer a été nouvellement élue à la présidence de la commission déthique pour une durée de quatre ans. Elle remplace Marco Noi, qui a été élu au Grand Conseil du Tessin et qui a démissionné de la présidence faute de temps.

Cette assemblée des membres extraordinaire fait l'objet d'un protocole, qui sera envoyé aux membres et qui pourra être consulté sur notre site Internet dans le domaine réservé aux membres. Nous sommes convaincus que nous serons de nouveau en mesure de tenir une assemblée des membres "physique » l'année prochaine et que nous pourrons lever ensemble le verre à un avenir plus optimiste.

Marianne Roth est directrice générale de l'ASP.

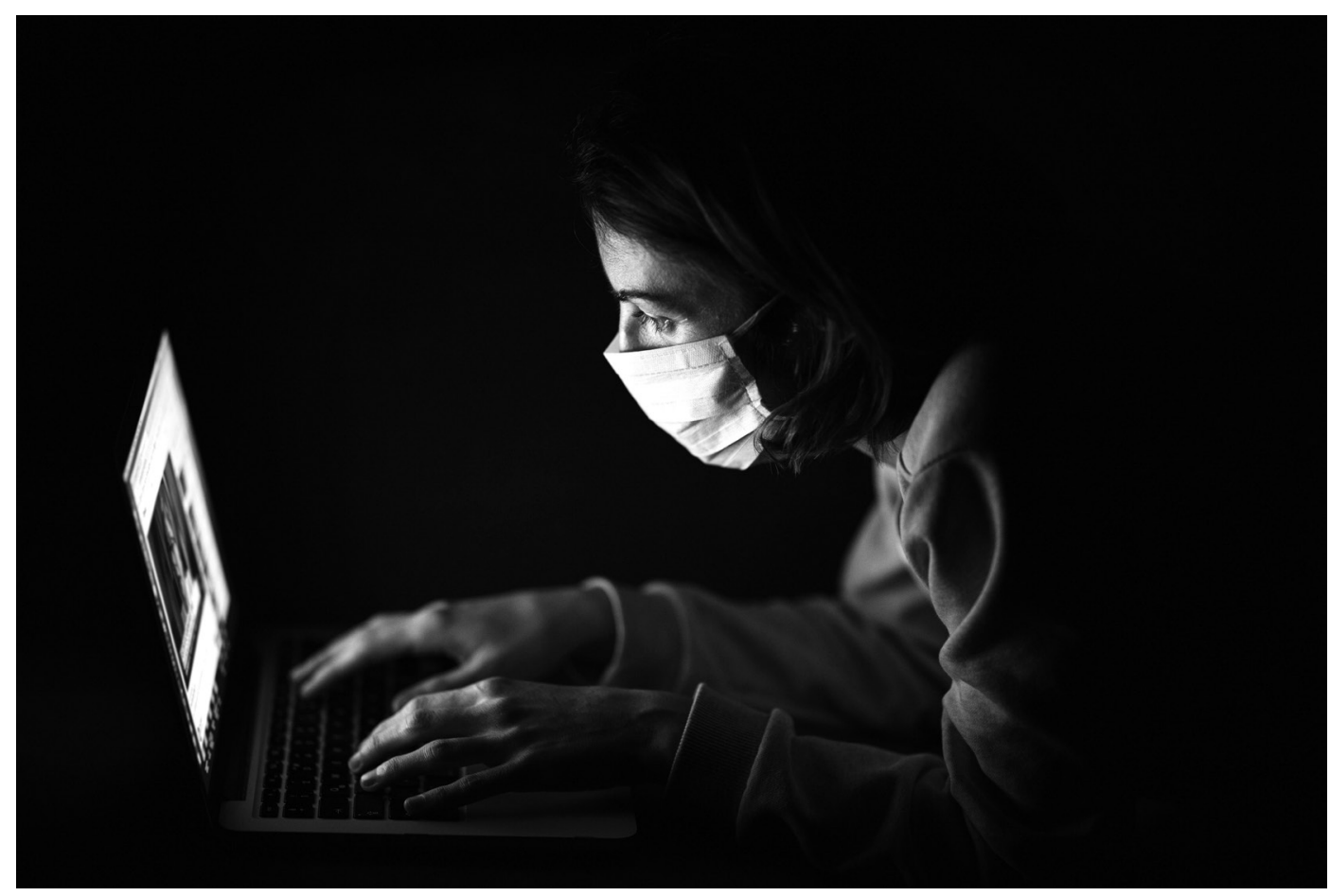

